\title{
Natalizumab treatment for multiple sclerosis: updates and considerations for safer treatment in JCV positive patients
}

\author{
Tratamento com Natalizumabe para esclerose múltipla: atualizações e considerações \\ para um tratamento mais seguro em pacientes positivos para o VJC \\ Luiz Henrique da Silva Nali ${ }^{1}$, Lenira Moraes², Maria Cristina Domingues Fink', Dagoberto Callegaro², \\ Camila Malta Romano ${ }^{1}$, Augusto Cesar Penalva de Oliveira ${ }^{3}$
}

\begin{abstract}
Natalizumab is currently one of the best options for treatment of patients with Multiple Sclerosis who have failed traditional prior therapies. However, prolonged use, prior immunosuppressive therapy and anti-JCV antibody status have been associated with increased risk of developing progressive multifocal leukoencephalopathy (PML). The evaluation of these conditions has been used to estimate risks of PML in these patients, and distinct (sometimes extreme) approaches are used to avoid the PML onset. At this time, the biggest issue facing the use of Natalizumab is how to get a balance between the risks and the benefits of the treatment. Hence, strategies for monitor JCV-positive patients undergoing Natalizumab treatment are deeply necessary. To illustrate it, we monitored JCV/DNA in blood and urine of a patient receiving Natalizumab for 12 months. We also bring to discussion the effectiveness of the current methods used for risk evaluation, and the real implications of viral reactivation.
\end{abstract}

Keywords: multiple sclerosis, Natalizumab, JCV, risk factors, progressive multifocal leucoencephalopaty, viruria.

RESUMO

Natalizumabe é atualmente uma das melhores opções para o tratamento de pacientes com Esclerose Múltipla que não respondem aos tratamentos tradicionais. No entanto, o seu uso prolongado, o uso de terapia imunossupressora prévia e o status sorológico antivírus JC têm sido associados com o risco aumentado de desenvolvimento de Leucoencefalopatia Multifocal Progressiva (LEMP). A avaliação destas condições tem sido utilizada para estimar os riscos do desenvolvimento de LEMP nestes pacientes, e abordagens distintas (por vezes extremas) são empregadas para evitar o aparecimento dessa patologia. Atualmente, o grande desafio está em obter um equilíbrio entre os riscos e os benefícios do tratamento com Natalizumabe. Assim, é crucial desenvolver estratégias para monitorar pacientes portadores do vírus JC sob tratamento com Natalizumabe. A título de ilustração, pesquisamos o vírus no sangue e na urina de um paciente sob tratamento durante 12 meses. Também discutimos a eficácia dos métodos atualmente utilizados para avaliação de riscos e as implicações reais de reativação viral.

Palavras-chave: esclerose múltipla, Natalizumabe, vírus JC, leucoencefalopatia multifocal progressiva, viruria.

Natalizumab (Tysabri), used for treatment of relapsingremitting multiple sclerosis (MS), is a monoclonal antibody directed to the a4 $\beta 1$ integrin, a subunit of an adhesion molecule expressed on the surface of $\mathrm{T}$ lymphocytes. The antibodies act by blocking the migration of $\mathrm{T}$ Lymphocytes from blood to the CNS through the blood brain barrier
(BBB) and attenuate the inflammatory effects ${ }^{1}$. The AFFIRM study showed that monotherapy with Natalizumab (NTZ) for 2 years decreased the relapse rate by $68 \%$ and the disability progression rate by $42 \%$ compared with placebo 2 . NTZ is well tolerated and the overall incidence of serious adverse events is low. Although the efficacy of NTZ is up to

\footnotetext{
1 Departamento de Moléstias Infecciosas e Parasitárias, Instituto de Medicina Tropical de São Paulo, Faculdade de Medicina, Universidade de São Paulo, Sao Paulo SP, Brazil;

${ }^{2}$ Hospital das Clínicas, Faculdade de Medicina, Universidade de São Paulo, Sao Paulo SP, Brazil;

${ }^{3}$ Instituto de Infectologia Emilio Ribas, Sao Paulo SP, Brazil.

Correspondence: Camila Malta Romano; Departamento de Moléstias Infecciosas e Parasitárias, Instituto de Medicina Tropical de São Paulo; Av. Dr. Eneas de Carvalho Aguiar, 470; 05403-000 São Paulo SP, Brasil; E-mail: cmromano@usp.br

Conflict of interest: There is no conflict of interest to declare.

Support: This research was made possible by FAPESP, project number 2010/10619-0. LHSN had a CAPES scholarship. The authors declare that they have no conflict of interest.
}

Received 21 January 2014; Received in final form 16 July 2014; Accepted 04 August 2014. 
3 times higher over disease-modifying drugs (DMDs), in 2005 it was announced the withdrawal of NTZ from the market since 2 patients with MS and 1 patient with Crohn disease were diagnosed with Progressive Multifocal Leukoencephalopathy (PML). In 2006, NTZ was reintroduced into the market and approved as monotherapy for the treatment of relapsing forms of MS. However, even with a careful administration protocol, PML cases in MS patients have been growing, with more than 400 cases reported so far (http://multiple-sclerosis-research.blogspot.com.br/2013/10/ natalizumab-pml-update-september-2013.html).

\section{A SHORT BACKGROUND OF PML}

Progressive multifocal leukoencephalopathy is a demyelinating disease of the central nervous system that usually leads to death or severe disability. PML is characterized by destruction of myelin-producing oligodendrocytes and astrocytes and has almost exclusively been reported in immunocompromised patients. Particularly, it manifests in individuals with reduced cellular immunity, including patients with HIV, hematological diseases, or receiving immunosuppressive therapies. Since the late 1980s until 2008 PML was responsible to be the cause of death of $4-5 \%$ of HIV-infected patients ${ }^{3,4}$.

JC virus is the PML etiological agent. It is a nonenveloped double-stranded circular DNA virus of 5,130 base pairs. The viral genome codes for six genes: Large and small T antigen, capsid genes VP1, VP2 and VP3, agnoprotein and the regulatory region (RR), which can be classified as the archetype or rearranged according to their structural features ${ }^{5}$.

The genetic structure of RR directly affects viral transcription and replication by change the level of DNA/protein and cofactors binding sites, thus leading to distinct cellular tropism ${ }^{6}$. The urinary shedding of JCV with archetype structure is frequent among healthy and immunocompromised individuals ${ }^{7,8,9,10}$, but rearranged forms with deletions, insertions and duplications are usually found in viruses from blood and brain of patients with $\mathrm{PML}^{11,12}$. Much less frequently, the rearranged form of JCV can be found in the urine of patients experiencing asymptomatic reactivation ${ }^{13}$. In addition to RR, variability in VP1 sequences found in CSF and brain of PML patients, but not in urine, also reinforces the relationship between the variants or genetic changes and viral tropism ${ }^{14,15}$.

Currently, the most accepted idea is that PML arises as a consequence of reactivation of latent JCV in the kidneys, leading to viremia and as a consequence, viruses present in blood and/or B-lymphocytes enter the brain and cause disease. However, viral reactivation in kidneys or blood preceding its migration to the brain is controversial since different groups have found viruses in brain of healthy individuals ${ }^{16,17}$ as well as no viremia at all in some affected patients. It was also found latent JCV in lymph, spleen, bone marrow and tonsil demonstrating that the virus may establishes latency in many tissues ${ }^{18,19}$.

\section{NATALIZUMAB AND PML}

PML in patients receiving Natalizumab was first reported in 2005 in three individuals during clinical studies. By the middle of 2011, all reported cases of PML in people receiving NTZ arose in patients who were under treatment for more than 1 year. In the same year, based on post-marketing reports, the overall risk of PML was estimated around 1.51 per 1,000 patients (95\%CI 1.27-1.79). More detailed historic investigation of these patients revealed that particular conditions could work as risk factors for PML development. For example, patients who developed PML were more likely to have been treated with immunosuppressant before receiving Natalizumab and the incidence of PML over time tended to be lower in the first 12 months of treatment but increased through time. Therefore, risk management strategies have been developed based on increased risk in patients with (i) anti-JCV antibodies, (ii) longer duration of Natalizumab treatment and (iii) prior immunosuppressive therapy ${ }^{20}$ (Figure 1). The risk of PML among patients with none of these conditions is very low and almost unchangeable through the treatment since the annual seroconversion rate is low.

Although the outcomes of natalizumab-treated patients with PML are generally better than those reported in HIV infected individuals, the clinical vigilance, early PML diagnosis, and cessation of Natalizumab treatment on suspicion of PML has been used to avoid the onset of the disease.

JCV is ubiquitous in human population and can be as prevalent as $80 \%$ according to some studies ${ }^{21,22,23,24,25}$. It is important to remind that JCV establishes latency in urinary tract and may be excreted during life without any consequence. In other words, JCV antibody detection does not provide all the necessary information regarding viral replication in MS patients undergoing NTZ treatment.

Given the risk to PML development increases according to the treatment extent ${ }^{26}$, some MS centers employ few months suspension of Natalizumab after one year of treatment (drug holiday) in order to restore the immune surveillance in JCV-positive patients. However, this approach remarkably increases the risk of rebound of MS activity ${ }^{27}$ and is not sufficient to extinguish the risk of developing the disease ${ }^{28}$. It is now evident that PML is a complex and not fully understood disease, in which viral and host factors might play a role in disease onset.

For this reason, the development of clinical and laboratory markers that assure the treatment safety for extended time in JC serologically positive individuals are pivotal. 


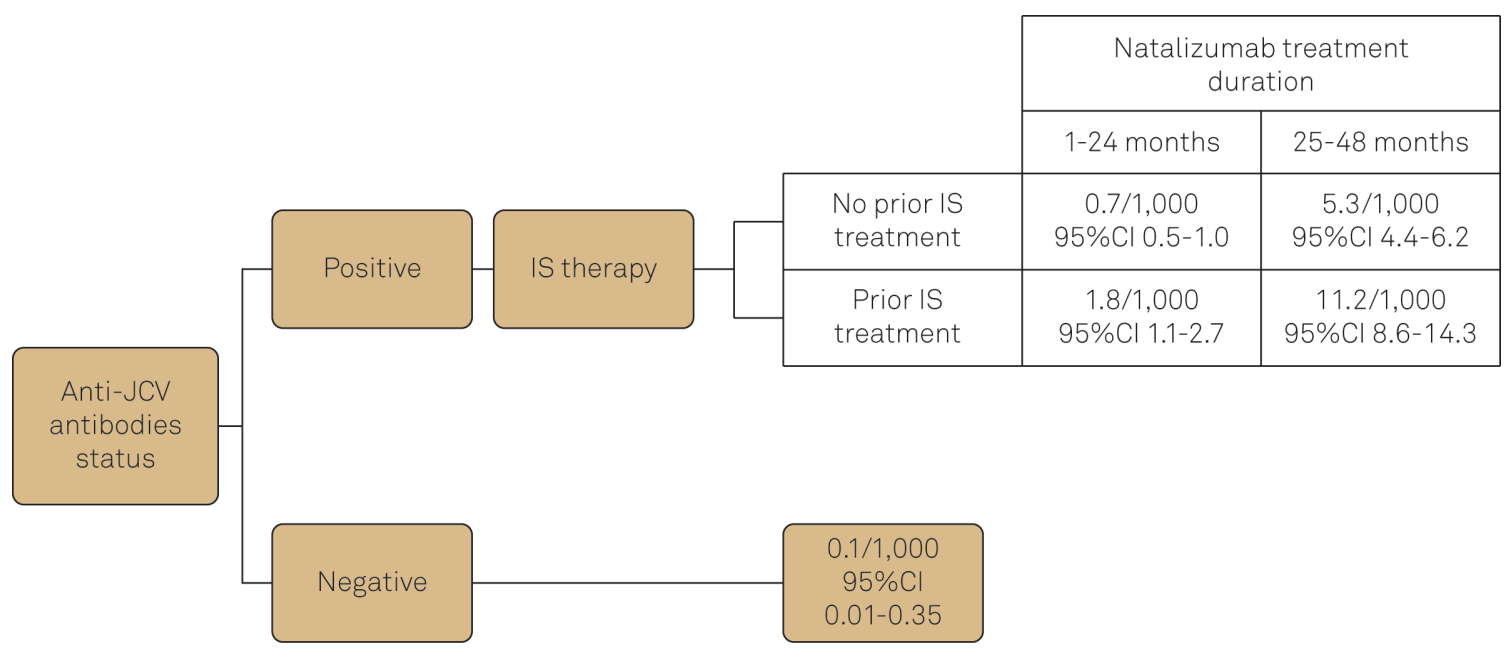

Figure 1. Risk for PML in MS patients under NTZ therapy. The risk is based on the time of treatment with NTZ, anti-JCV antibodies status and previous Immunosuppressive therapy. IS=Immunosuppressive (adapted from http://multiple-sclerosis-research. blogspot.com.br/)

To illustrate it, we describe the JCV replication dynamics in the urine and blood of a JCV positive MS patient receiving NTZ over 12 months and the detailed molecular investigation of the complete VP1 gene and RR.

\section{THE FOLLOW UP}

Urine and blood samples from a 38 year-old female patient, with MS first diagnosed as relapsing-remitting form in 1990 and receiving NTZ were monthly monitored through Real Time PCR for one year for the presence and viral load of $\mathrm{JCV}^{29}$. From all positive samples, we sequenced the VP1 and RR (see Table for primers used in both reactions).

The patient was previously treated with Glatiramer acetate and interferon $\beta$-1A. She responded well to the NTZ and no relapses were reported during the follow-up. The average expanded disability status scale (EDSS) score was evaluated before NTZ introduction (EDSS=6) and remained stable throughout the treatment.

JCV DNA was not detected in blood samples in any timepoint evaluated. However, all the urine samples were positive, including the one collected before NTZ introduction. The viral load, which was about 770,000 copies $/ \mathrm{ml}$ at the first sampling, experienced a slightly decrease in the first

Table. Sets of primers used for RR and VP1 amplification for sequencing.

\begin{tabular}{lcc}
\hline Primers & Viral region & \multicolumn{1}{c}{ Sequence } \\
JCRS* & RR & ATTAGTGCAAAAAAGGGAAAAACAAGGG \\
JCRAS* & RR & CTCGGATCCAGCTGGTGACAAGCCAAAACAG \\
70_F & VP1 & CTCAATGGATGTTGCCTTTAC \\
991_R & VP1 & CCTCAAAAACTCTAACCTCCTC \\
\hline
\end{tabular}

*(Pfister et al., 2001). three months of treatment but significantly increased after the fourth month, reaching to $1.10^{9}$ copies $/ \mathrm{ml}$ during the $8^{\text {th }}, 9^{\text {th }}$ and $10^{\text {th }}$ months of treatment (Figure 2). This observation is in keeping with the Laroni et al., that found that viruria could occur before the Natalizumab introduction, but gradually increase during the treatment ${ }^{30}$.

The JCV/VP1 gene and RR were successfully sequenced from viruses sampled at all time-points (the RR from the last three months was also cloned to deep investigate putative mutants present as minor population) and no nucleotide change was detected in the consensus sequences during the follow-up. Nevertheless, a careful inspection of the electropherograms revealed the emergence of a non-synonymous change at nucleotide 86 of the VP1 gene, at the very end of the N' terminal region (aminoacid site 29) in viruses

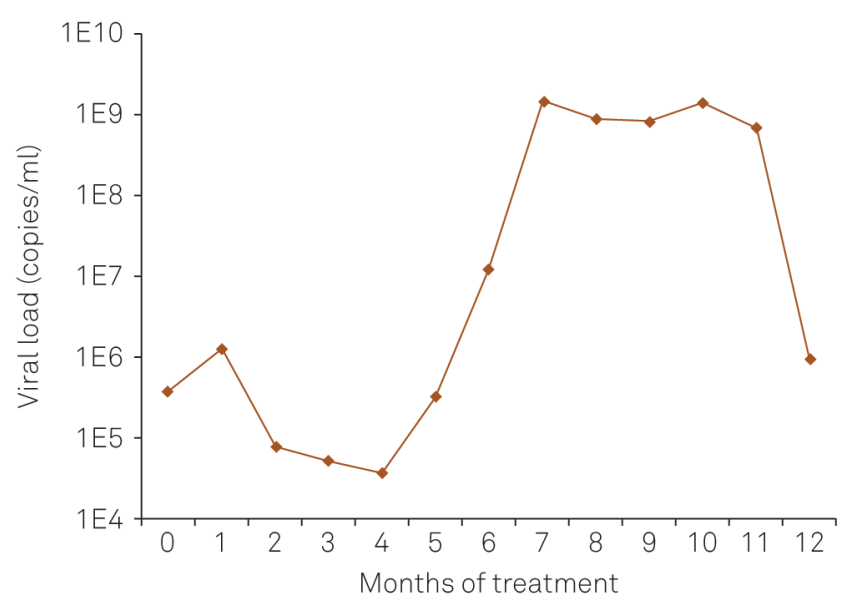

Figure 2. Viral load/ml in urine samples. The graph shows the number of JC viruses/ml detected through Real Time PCR in urine at each time-point. Time 0 corresponds to the sample collected immediately before the first Natalizumab infusion. 


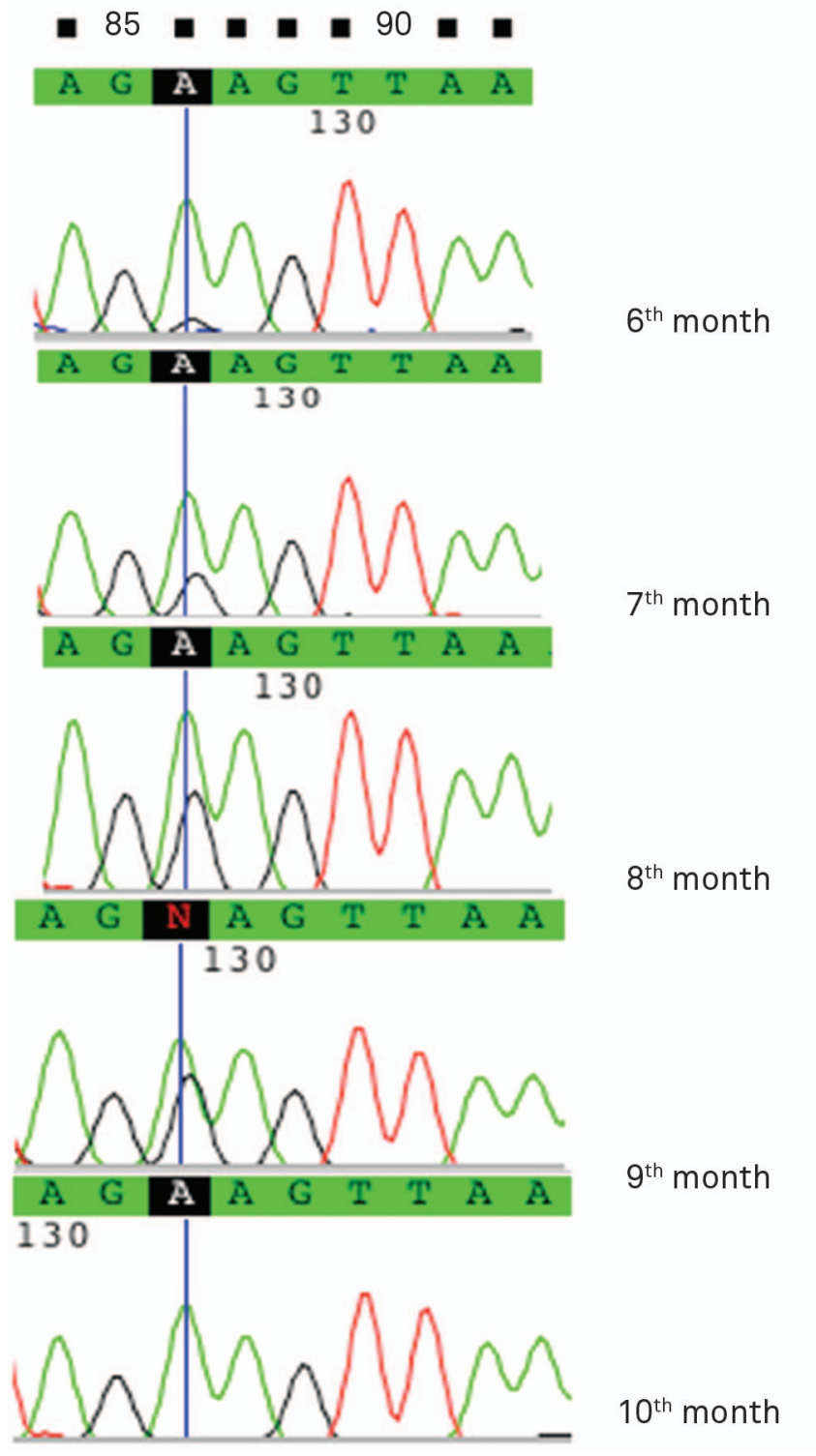

Figure 3. Electropherograms of VP1 sequences. Selected regions evidence the mixture detected in VP1 sequences. Adenine is present in the original and predominant population and Guanine emerged as variants. Variants were detected at the $6^{\text {th }}$ to $9^{\text {th }}$ months of the treatment.

from the sixth, seventh, eighth and ninth months of treatment (Figure 3). This change (Adenine to Guanine) would lead to the substitution of a glutamate to glycine (E29G). However, these mutants never reached to the majority population, and were no longer observed in the following months. This mutation was not related to any change already described as associated to PML.

Intra-host JCV variability, especially in the RR region is almost a consensus for PML patients, but the origin of the mutants has been subject of investigation. Some argue that the high rate of viral replication in urine or blood of an infected patient allows the emergence of mutant viruses with different tropism ${ }^{31,32}$. In contrast, it has also been suggested that variants with different tropism circulates among the population, and the infection by a more or less pathogenic strain happens by chance ${ }^{29}$. There is also the possibility that JCV establish latency in other tissues besides the urinary tract, as indicated by findings of JCV in brain of healthy individuals ${ }^{16,17,18}$. It is in accordance to the usual presence of archetype virus in urine but rearranged forms in blood and brain of PML individuals.

Here we showed that despite no JCV rearranged forms came out in the urine and no viremia occurred after 12 months of treatment, VP1 mutant viruses emerged in the urine concomitant to the increase of the viral load (see Figures 2 and 3). The emergence of variants during extensive viral replication is not surprising for viruses that experience high evolutionary rates ${ }^{33,34,35}$. Nevertheless, JCV, similarly to other DNA viruses, is genetically stable through time since its substitution rate ranges between $10^{-7}$ to $10^{-8} \mathrm{~s} / \mathrm{s} / \mathrm{y}^{36}$. Thus, it is less likely (although not impossible) that JCV variant, observed in this study, results from a within-patient mutation emergence.

We then envisage a scenario where the patient analyzed was infected during its lifetime by distinct variants, and the virus predominantly detected during the whole study was probably the one with the best fitness (variant A). Through the follow-up, the variant that emerged at the sixth month (variant B) was reactivated, possibly as a consequence of the Natalizumab treatment or any other unknown cause.

In situations where high-load persistent viral infection is already established and viral replication is constant, functional impairments or low frequencies of virus-specific $\mathrm{T}$ cells is not uncommon ${ }^{37}$. Therefore, it is possible that the emergence of the variant $\mathrm{B}$ concomitant to the already established variant A caused both, increased viral load, and stimulated the cellular immune response. As a consequence, the variant B was controlled, the viral load decreased and only the original (and possibly less immunogenic) viruses remained detectable.

Furthermore, it is also possible that the inefficient viral control is consequence of the effects of NTZ in the immune system. NTZ was showed to disturb the balance between cytokines, up regulating some pro inflammatory cytokines ${ }^{38}$ and decreasing the expression of the co-stimulatory molecule CD134 on CD4(+)CD26(HIGH) T-cells ${ }^{39}$. Also, Perkins and coworkers reported that patients receiving Natalizumab who developed PML do not present JCV-specific T cell response or had JCV-specific CD4 T cell responses uniquely dominated by IL-10 production ${ }^{40}$. Unfortunately, no immunological test was performed in the present study to confirm if this would be the case here. Altogether, the above-discussed data reinforce that PML in NTZ patients is a combination of altered cellular and cytokine expression and viral factors.

In summary, the availability of NTZ represents a real gain in terms of better quality of life for MS patients, but it also 
resulted in a new group of risk for PML. While the minimal risk of PML among these patients is as low as $0.00006 \%$ the maximal risk can reach to $1.17 \%$ in a JCV carrier with previous exposure to other chemotherapies and receiving NTZ for more than 24 months ${ }^{20}$.

The putative JCV reactivation, associated to an inefficient viral control caused by Natalizumab support that both viral replication and immunological status of the patients should be monitored through the treatment in order to identify patients at imminent risk of PML without the need to suspend arbitrarily the therapy.

\section{Acknowledgments}

We thank the Neuroscience Group of Instituto de Infectologia Emílio Ribas for helpful discussions. We are also in debt with Rosa M. Marcusso for the administrative support.

\section{References}

1. Yednock TA, Cannon C, Fritz LC, Sanchez-Madrid F, Strinman L, Karin N. Prevention of experimental autoimmune encephalomyelitis by antibodies against alpha 4 beta 1 integrin. Nature. 1992;356(6364):63-6. http://dx.doi.org/10.1038/356063a0

2. Polman CH, O'Connor PW, Havrodova E, Hutschinson M, Kappos L, Miller DH et al. A randomized, placebo-controlled trial of natalizumab for relapsing multiple sclerosis. N Engl J Med. 2006;354(9):899-910. http://dx.doi.org/10.1056/NEJMoa044397

3. Greenlee JE. Progressive multifocal encephalopathy. Handb Clin Neurol. 1998;123:399-430. http://dx.doi.org/10.1016/b978-0-44453488-0.00017-1

4. Vidal JE, Oliveira ACP, Fink MC, Pannuti CS, Trujillo JR. Aids-related progressive multifocal leukoencephalopathy: a retrospective study in a referral center in Sao Paulo, Brazil. Rev Inst Med Trop São Paulo. 2008;50(4):209-12. http://dx.doi.org/10.1590/s003646652008000400004

5. Imperiale MJ. Polyomaviruses. In: Knipe DV, Howley PM, editors. Field's virology. New York: Lippincott Williams \& Wilkins; 2007. p. 2263-98

6. Ravichandran $\mathrm{V}$, Major EO. Viral proteomics: a promising approach for understanding JC virus tropism. Proteomics. 2006;6(20):5628-36. http://dx.doi.org/10.1002/pmic.200600261

7. Behzad-Behbahani A, Klapper PE, Vallely PJ, Cleator CM, Khoo SH. Detection of BK virus and JC virus DNA in urine samples from immunocompromised (HIV-infected) and immunocompetent (HIVnon-infected) patients using polymerase chain reaction and microplate hybridisation. J Clin Virol. 2004;29(4):224-9. 10.1016/S13866532(03)00155-0

8. Rossi A, Delbue S, Mazziotti R, Vlli M, Borghi E, Mancuso R et al. Presence, quantitation and characterization of $\mathrm{JC}$ virus in the urine of Italian immunocompetent subjects. J Med Virol. 2007;79(4):408-12. http://dx.doi.org/10.1002/jmv.20829

9. Nali LHS, Centrone CC, Urbano PRP, Penalva-de-Oliveira AC, Vidal JE, Miranda EP et al. High prevalence of the simultaneous excretion of polyomaviruses JC and BK in the urine of HIV-infected patients without neurological symptoms in Sao Paulo, Brazil. Rev Inst Med Trop São Paulo. 2012;54(4):201-5. http://dx.doi.org/10.1590/S003646652012000400004

10. Yogo Y, Kitamura T, Sujimoto C, Ueki T, Aso Y, Hara K et al. Isolation of a possible archetypal JC virus DNA sequence from nonimmunocompromised individuals. J Virol. 1990;64(6):3139-43.

11. Pfister LA, Letvin NL, Koralnik IJ. JC virus regulatory region tandem repeats in plasma and central nervous system isolates correlate with poor clinical outcome in patients with progressive multifocal leukoencephalopathy. J Virol. 2001;75(12):5672-6. http://dx.doi.org/ 10.1128/jvi.75.12.5672-5676.2001

12. Yogo $Y$, Matsushina-Ohno T, Hayashi T, Sujimoto S, Sakurai M, Kanazawa I. JC virus regulatory region rearrangements in the brain of a long surviving patient with progressive multifocal leukoencephalopathy. J Neurol Neurosurg Psychiatry. 2001;71(3):397-400. http://dx.doi.org/10.1136/jnnp.71.3.397
13. Chen Y, Bord E, Tompkins T, Miller J, Tan CS, Kinkel RP et al. Asymptomatic reactivation of $\mathrm{JC}$ virus in patients treated with natalizumab. N Engl J Med. 2009;361(11):1067-74. http://dx.doi.org/ 10.1056/NEJMoa0904267

14. Marshall LJ, Major EO. Molecular regulation of JC virus tropism: insights into potential therapeutic targets for progressive multifocal leukoencephalopathy. J Neuroimmune Pharmacol. 2010;5(3):404-17. http://dx.doi.org/10.1007/s11481-010-9203-1

15. Reid CE, Li H, Sur G, Carmillo P, Bushnell S, Tizard R al. Sequencing and analysis of JC virus DNA from natalizumab-treated PML patients. J Infect Dis. 2011;204(2):237-44. http://dx.doi.org/10.1093/ infdis/jir256

16. White III FA, Ishaq M, Stoner GL, Frisque RJ. JC virus DNA is present in many human brain samples from patients without progressive multifocal leukoencephalopathy. J Virol. 1992;66(10):5726-34.

17. Elsner C, Dörries K. Evidence of human polyomavirus BK and JC infection in normal brain tissue. Virology. 1992;191(1):72-80. http://dx.doi.org/10.1016/0042-6822(92)90167-n

18. Monaco MC, Jensen PN, Hou J, Durham LC, Major EO. Detection of JC virus DNA in human tonsil tissue: evidence for site of initial viral infection. J Virol. 1998;72(12):9918-23.

19. Tan CS, Ellis LC, Wüthrich C, Ngo L, Broge TA, Saint-Aubyn J et al. JC virus latency in the brain and extraneural organs of patients with and without progressive multifocal leukoencephalopathy. J Virol. 2010;84(18):9200-9. http://dx.doi.org/10.1128/jvi.00609-10

20. Sorensen PS, Bertolotto A, Edan G, Giovannnoni G, Gold R, Havrdova $E$ et al. Risk stratification for progressive multifocal leukoencephalopathy in patients treated with natalizumab. Mult Scler. 2012;18(2):143-52. http://dx.doi.org/10.1177/1352458511435105

21. Antonsson A, Green AC, Mallitt KA, O'Rourke PK, Pawlita M, Waterboer $T$ et al. Prevalence and stability of antibodies to the $\mathrm{BK}$ and JC polyomaviruses: a long-term longitudinal study of Australians. J Gen Virol. 2010;91(7):1849-53. http://dx.doi.org/ 10.1099/vir.0.020115-0

22. Egli A, Infanti L, Dumoulin A, Buser A, Samaridis J, Stebler C et al. Prevalence of polyomavirus $\mathrm{BK}$ and $\mathrm{JC}$ infection and replication in 400 healthy blood donors. J Infect Dis. 2009;199(6):837-46. http://dx.doi.org/10.1086/597126

23. Bozic C, Richman S, Plavina T, Natarajan A, Scanlon JV, Subramanyam $\mathrm{M}$ et al. Anti-John Cunnigham virus antibody prevalence in multiple sclerosis patients: baseline results of STRATIFY-1. Ann Neurol. 2011;70(5):742-50. http://dx.doi.org/10.1002/ana.22606

24. Kean JM, Rao S, Wang M, Garcea RL. Seroepidemiology of human polyomaviruses. PLoS Pathog. 2009;5(3):e1000363. http://dx.doi.org/ 10.1371/journal.ppat.1000363

25. Trampe AK, Hemmelmann C, Stroet A, Haghikia A, Hellwig K, Wiendl $\mathrm{H}$ et al. Anti-JC virus antibodies in a large German natalizumabtreated multiple sclerosis cohort. Neurology. 2012;78(22):1736-42. http://dx.doi.org/10.1212/WNL.0b013e3182583022 
26. Fernandez 0 . Best practice in the use of natalizumab in multiple sclerosis. Ther Adv Neurol Disord. 2013;6(2):69-79. http://dx.doi.org/ 10.1177/1756285612470401

27. Killestein J, Vennegoor A, Strijbis EM. Natalizumab drug holiday in multiple sclerosis: poorly tolerated. Ann Neurol. 2010;68(3):392-5. http://dx.doi.org/10.1002/ana.22074

28. Gheuens S, Smith DR, Wang X, Alsop DC, Lenkinski RE, Koralnik IJ. Simultaneous PML-IRIS after discontinuation of natalizumab in a patient with MS. Neurology. 2012;78(18):1390-3. http://dx.doi.org/ 10.1212/WNL.0b013e318253d61e

29. Pal A, Sirota L, Maudru T, Peden K, Lewis AM. Real-time, quantitative PCR assays for the detection of virus-specific DNA in samples with mixed populations of polyomaviruses. J Virol Methods. 2006;135(1):32-42. http://dx.doi.org/10.1016/j.jviromet.2006.01.018

30. Laroni A, Giacomazzi CG, Grimaldi L, Gallo P, Sormani MP, Bertolotto A et al. Urinary JCV-DNA testing during natalizumab treatment may increase accuracy of PML risk stratification. J Neuroimmune Pharmacol. 2012;7(3):665-72. http://dx.doi.org/10.1007/s11481-0129366-z

31. Gosert R, Kardas P, Major EO, Hirsch HH. Rearranged JC virus noncoding control regions found in progressive multifocal leukoencephalopathy patient samples increase virus early gene expression and replication rate. J Virol. 2010;84(20):1048-56. http://dx.doi.org/ 10.1128/jvi.00614-10

32. Raj GV, Khalili K. Transcriptional regulation: lessons from the human neurotropic polyomavirus, JCV. Virology. 1995;213(2):283-91. http://dx.doi.org/10.1006/viro.1995.0001

33. Shankarappa R, Margolick JB, Gange SJ, Rodrigo AG, Upchurch D, Farzadegan $\mathrm{H}$ et al. Consistent viral evolutionary changes associated with the progression of human immunodeficiency virus type 1 infection. J Virol. 1999;73:10489-1502.

34. Rambaut A, Posada D, Crandall KA, Holmes EC. The causes and consequences of HIV evolution. Nat Rev Genet. 2004;5(1):52-61. http://dx.doi.org/10.1038/nrg1246

35. Ueda E, Enomoto N, Sakamoto N, Hamano K, Sato C, Izumi N et al. Changes of $\mathrm{HCV}$ quasispecies during combination therapy with interferon and ribavirin. Hepatol Res. 2004;29(2):89-96. http://dx.doi. org/10.1016/j.hepres.2004.02.014

36. Hatwell JN, Sharp PM. Evolution of human polyomavirus JC. J Gen Virol. 2000;81(5):1191-200.

37. Fuse S, Molloy MJ, Usherwood EJ. Immune responses against persistent viral infections: possible avenues for immunotherapeutic interventions. Crit Rev Immunol. 2008;28(2):159-83. http://dx.doi.org/ 10.1615/critrevimmunol.v28.i2.40

38. Benkert TF, Dietz L, Hartmann EM, Leich E, Rosenwald A, Serfling E et al. Natalizumab exerts direct signaling capacity and supports a pro-inflammatory phenotype in some patients with multiple sclerosis. PLoS ONE. 2012;7(12):e52208. http://dx.doi.org/10.1371/ journal.pone.0052208

39. Bornsen L, Christensen JR, Ratzer R, Oturai AB, Sørensen PS, Søndergaard $\mathrm{HB}$ et al. Effect of natalizumab on circulating CD4+ T-cells in multiple sclerosis. PLoS ONE 2012;7(11):e47578. http://dx.doi.org/10.1371/journal.pone.0047578

40. Perkins MR, Ryschkewitsch C, Liebner JC, Monaco MCG, Himelfarb D Ireland $\mathrm{S}$ et al. Changes in JC virus-specific $\mathrm{T}$ cell responses during natalizumab treatment and in natalizumab-associated progressive multifocal leukoencephalopathy. PLoS Pathog. 2012;8(11):e1003014. http://dx.doi.org/10.1371/journal.ppat.1003014 